\title{
The Electronic Systems And Taxpayer Compliance
}

\author{
R. M. Oktaviani, R. Wahono, C. Srimindarti, and P. Hardiningsih \\ Faculty of Economics and Business \\ Stikubank University,Semarang \\ meitarachma@edu.unisbank.ac.id
}

\begin{abstract}
Tax administration reform is a step taken by the government to increase the taxpayer compliance. This study aimed to examine and analyze the effect of e-Billing and e-Filing systems on the taxpayer compliance. In addition, it was also meant to test and analyze the influence of understanding the internet as a moderating relationship between the implementation of the e-Filing system on the taxpayer compliance.The sample of 105 respondents. The results of this study indicated that the application of e-Billing system did not affect the taxpayer compliance, while the application of e-Filing system has a positive and significant effect on the tax compliance. While understanding the internet is proven to strengthen the positive relationship between the application of e-Filing system to the taxpayer compliance.
\end{abstract}

Keywords: Application of e-Billing, e-Filing, understanding of the internet, tax compliance.

\section{INTRODUCTION}

Tax is a source of income that has an important role in a country. The tax plays important roles such as to support economic activities, to drive the government activities, and to provide public facilities. In Indonesia the applicable tax collection system is a selfassesment system where the taxpayer is given the authority to determine the amount of the tax owed. In the implementation of the taxation in Indonesia, the taxpayers are required to make the tax payments and delivery of Tax Return in accordance with the time set by the Directorate General of Taxes. This needs to be considered because if the taxpayer carries out negligence, the risk is that the person concerned can be fined (Oktaviani and Chusaeni, 2018).

Prior to the tax reform, all taxation activities were carried out manually or carried out directly at the tax office, including Pratama Semarang Tax Office, Candisari, which is one of the institutions under the auspices of the Directorate General of Taxes having 99,398 registered taxpayers. The implementation of a manual taxation system by the government often facing obstacles that affected the level of tax compliance. The constraints of the manual taxation system include the administrative process which is quite complicated, time consuming, and not economical because it requires a lot of paper usage. If it continues it can lead to negative perceptions by taxpayers that can cause the decrease of the the level of compliance.

To overcome the problems in the manual taxation system, the Directorate General of Taxes make some efforts by carrying out modern tax administration reforms with online systems. The ease of online systems is applied in terms of tax services, namely the online 
tax payment system (e-Billing) and the delivery system of Tax Return online (e-Filing). In all Primary Tax Service Offices in Indonesia, e-Billing and e-Filing system services have been implemented so that taxpayers no longer need to come to the tax service office if they are going to submit a Tax Return (SPT) and pay taxes. With the electronic tax system, it is expected that compliance with taxation obligations in Indonesia can be carried out well.

With the increasing number of internet users in Indonesia, more effective and efficient tax reforms can be applied.This can be seen from the following Data on Internet User Penetration in Indonesia in 2016:

Table 1. Indonesian Internet User Penetration Data

\begin{tabular}{ccc}
\hline Location & Internet user & $\begin{array}{c}\text { Percentage } \\
(\mathbf{\%})\end{array}$ \\
\hline Sumatra & 20.752 .185 & $15,7 \%$ \\
Jawa & 86.339 .350 & $65 \%$ \\
Bali dan Nusa & 6.148 .796 & $4,7 \%$ \\
Kalimantan & 7.685 .992 & $5,8 \%$ \\
Sulawesi & 8.454 .592 & $6,3 \%$ \\
Maluku dan Papua & 3.330 .596 & $2,5 \%$ \\
Jumlah & 132.711 .511 & $100 \%$ \\
\hline
\end{tabular}

Source: (Indonesian Internet Service Provider Association, 2016)

Based on the results of an internet survey from the (Indonesian Internet Service Provider Association, 2016) showed that the number of internet users in Indonesia reached $132,711,511$ users. If compared with the total population in Indonesia, which amounts to 256.2 million, it can be concluded that internet users in Indonesia account for $52.5 \%$ of the total population of Indonesia. A significant increase compared to 2014, where the population of Indonesia at that time was 252.4 million with the number of internet users 88.1 million users or $34.9 \%$ of the total population in Indonesia.

The interest of the Indonesian people in using electronic Tax Return is higher for the 2017 tax year. The number of annual Tax Return submitted electronically reaches $8,673,419$ or $81.9 \%$ of all Tax Return submitted until March 31 2018. Submission of electronic Return grew by $21.6 \%$. The electronic way here is through e-Filing. Whereas the submission of manual Tax Return decreased $12 \%$ to $1,916,229$ or $18.1 \%$ of all Tax Return submitted until March 31, 2018, seen from the following data:

Table 2. Media for Submission of 2017 Year Tax Returns

\begin{tabular}{ccc}
\hline Submission Media & $\begin{array}{c}\text { Tax } \\
\text { Returns } \\
\mathbf{( 2 0 1 7 )}\end{array}$ & $\begin{array}{c}\text { Percentage } \\
(\mathbf{\%})\end{array}$ \\
\hline ElektronicTax Returns (SPT) & 8.673 .419 & $81,9 \%$ \\
Manual Tax Returns (SPT) & 1.916 .229 & $18,1 \%$ \\
Total & 10.589 .648 & $100 \%$ \\
\hline
\end{tabular}


Source: (Directorate General of Taxation, 2018)

The advantages of online taxation systems compared to manual systems include that the administration process is simpler because it uses a computer system so that it can be done anytime and anywhere. Online systems can also be accessed quickly because it is connected via the internet so that it can save timeand is more economical because it reduces paper use. Based on the phenomenon above, the application of e-Billing and eFiling systems is interesting to the study because of their online application. In this case the taxpayer is required to understand how to operate the internet properly so as not to experience obstacles when accessing this system (Tresno and Rizky, 2012).

The previous research on the effect of implementing the e-Billing system on taxpayer compliance show different results. The results of research conducted by (Ersania and Merkusiwati, 2018) and (Handayani, 2017) show that the application of e-Billing has a positive and significant effect on taxpayer compliance. While research conducted by (Rahmah et al., 2018) shows different results, that is the application of e-Billing system does not effect taxpayer compliance.

The relationship between the implementation of e-Filing system and taxpayer compliance also shows different results. Research conducted by (Agustiningsih and Isroah, 2016) and (Jayanti, 2017) regarding the application of e-Filing system to taxpayer compliance shows that the implementation of e-Filing system has a positive and significant effect on taxpayer compliance. While research conducted by (Handayani and Tambun, 2016) show different results, that is the application of e-Filing system does not affect taxpayer compliance.

In addition to being able to operate the e-Filing system properly it requires understanding the internet by taxpayers. The research conducted by (Suprayogo and Hasymi, 2018) shows that understanding the internet strengthens the positive relationship of the effect of implementing the e-Filing system on tax compliance. While research with different results was carried out by (Lado and Budiantara, 2018) which show that understanding the internet did not moderate the effect of implementing the e-Filing system on tax compliance.

The above explanation becomes the motivation which drives this research to determine whether the application of e-Billing and e-Filing systems can improve taxpayer compliance. Based on the background and motivation that drives why this research was conducted, the research questions that will be analyzed in this study emerge. The emerging research questions are related to: 1). How does the e-Billing system affect taxpayer compliance; 2).How is the effect of implementing the e-Filing system on tax compliance; and 3). What is the role of understanding the internet asa moderating element to the relationship between the application of the e-Filing system to tax compliance.

There are two benefits to be achieved from this study, namely theoretical and practical benefits. Theoretical benefits of this study examine the effect of implementing eBiling and e-Filing systems on taxpayer compliance with the understanding of the internet as a moderating variable. The results of this research are expected to contribute to the development of literature and research in the field of accounting, especially in the field of taxation. The practical benefits for the Directorate General of Taxes provide an overview of the influence of the online taxation system that has been implemented so as to improve 
the quality of tax system services and make socialization so that the public (taxpayers) can find complete tax information, so it will increase taxpayer compliance in paying taxes and delivering Online Notification (SPT).

\section{THEORITICAL REVIEW}

Theory of Technology Acceptance Model (TAM). Technology Acceptance Model (TAM) is one theory about the use of information technology systems that are considered very influential and are generally used to explain individual acceptance of the use of information technology systems. The purpose of the Technology Acceptance Model (TAM) is more specifically to explain the behavior of computer users (computer usage behavior).Individual behavior is influenced by perceived ease and perceived usefulness (Ersania and Merkusiwati, 2018). Ease of use perceived is the extent to which someone believes that a technology is easy when used. Whereas the usefulness perceived is how far someone believes that using a technology can improve its performance. The relationship between the Technology Acceptance Model (TAM) theory and this research is that taxpayers believe that the e-Billing system is easy to operate in the process of paying taxes and taxpayers who believe that e-Filing systems when operated can improve their performance in delivering SPTs. then taxpayer compliance will increase (Shroff and Deneen, 2012).

Attribution Theory. Attribution theory is a theory that was first proposed by Fritz Heider in 1958. Attribution theory states that the behavior of an individual is influenced by factors that exist within the individual (internal factors) and factors that originate outside the individual (external factors) (Handayani, 2017). The relationship of attribution theory with this research is that taxpayers who will use electronic taxation systems are influenced by their own inner abilities. In this case the understanding of the internet is as a supporting factor that influences taxpayers to use the e-Filing system. Understanding the internet will make it easier for taxpayers to access the e-Filing system properly. In addition, taxpayers can also obtain information when having insufficient knowledge in operating the e-Filing system so that it will add insight to the taxpayer.

Taxpayer Compliance. Tax compliance can be determined as a requirement where the taxpayer fulfills all the requirements and tax commitments (Oktaviani et al., 2017), (Rahman, 2010) and (Alabede and Idris, 2012). Tax obligations that must be met by taxpayers, namely: 1). register to get a Taxpayer Identification Number, 2). Reporting its business to be confirmed as a Taxable Entrepreneur, 3). Calculate the tax payable, calculate the tax that has been deducted by other parties, pay, and report the tax yourself correctly, 4). Fully fill in the Notification Letter, and enter the Tax Service Office within the specified time limit, 5). Organizing bookkeeping or recording, 6). When inspected the taxpayer is required to show a bookkeeping report or notes, and documents relating to the income obtained, and 7). If when disclosing books, records, or documents and information requested, the taxpayer is bound by an obligation to keep it a secret, then the obligation to keep it confidential is nullified by requests for inspection purposes (Mardiasmo, 2016). 
While the rights possessed by taxpayers, namely: 1). Submit objection letters and appeal letters, 2). Receive proof of receipt, 3). Make corrections to the Notification that has been entered, 4). Applying for a request to postpone the Notification. 5), Applying for a delay in paying taxes, 6). Submit a tax calculation request that is imposed in a tax assessment letter, 7). Request a refund of excess tax payments, 8). Submit a request for the elimination and reduction of sanctions, as well as correcting the wrong tax assessment, 9). Give authority to people to carry out their tax obligations, and 10). Request proof of withholding or tax collection (Mardiasmo, 2016).

Based on PMK 192/PMK.03/2007 concerning Taxpayers with Specific Criteria in the Framework of Returns for the Excess of Payment of Taxes, taxpayers with certain criteria are referred to as compliant taxpayers if they fulfill the following conditions (Lado and Budiantara, 2018): 1). Timely in submitting a Tax Return (SPT), on time in the submission of Annual Tax Return (SPT) in the last three years, namely the end of the third month after the tax year. 2). Has no tax arrears for all types of taxes, except tax arrears that have obtained unemployment permits or delayed tax payments. Arrears of tax are installments of tax that have not been repaid at or after the date of imposition of fines. 3). The financial statements must be audited by a Public Accountant or Government Financial Supervisory Institution with a Fair Without Exception opinion for three consecutive years.Unqualified Opinion without exception is given by the auditor if there are no overall material errors in the financial statements presented, in other words the financial statements are in accordance with Financial Accounting Standards (SAK). 4). Never been convicted of committing a criminal offense in the field of taxation based on an audit decision that has permanent legal force within the last five years.

Application of e-Billing System. According to PER-26/PJ/2014, e-Billing is an electronic payment method using billing code. A billing code is an identification code issued through a billing system for a type of deposit that a taxpayer will make. Tax payment transactions are made through a Bank or Perception Post using billing codes. The process of paying taxes using the e-Billing system by taxpayers must go through the following stages: 1). Registration of a Billing account (if you don't have a Billing account) on the official website of the Directorate General of Taxes. 2). Making a Billing Code on the official website of the Directorate General of Taxes. 3). Depositing tax debt to a Bank or Perception Post by carrying a Billing Code. Some methods of service are provided in making Billing Codes and in depositing taxes to Banks or Perception Posts. It aims to provide the best service for taxpayers and provide convenience in the process of payment using e-Billing. So, it can be concluded that e-Billing is payment of taxes through electronic media by utilizing billing codes as transaction codes (Handayani, 2017).

Implementation of the e-Filing System. Through the Decree of the Directorate General of Taxes No. KEP-88 / PJ / 2004 the e-Filing system was officially launched. According to the Directorate General of Tax Regulation SE-47/PJ/2008 Article 1 states that e-Filing is a method of delivering Notification (SPT) online and real time through an Application Service Provider. So it can be concluded that e-Filing is a way of submitting online Notification (SPT) that can be done through internet media. 
The application of the e-Filling system has several advantages for taxpayers, namely: 1). Letter Submission Notification is faster because it can be done anywhere and anytime, 24 hours a day, 7 days a week because it utilizes the internet network. 2). The cost of reporting a Notification Letter is cheaper because to access the website of the Directorate General of Taxes is free of charge. 3). Calculation is done quickly because it uses a computer system. 4). It's easier because pingisian Notification in the form of a wizard. 5). The data submitted by the taxpayer is always complete because there is a validation of filling out the Notification Letter. 6). More environmentally friendly because it minimizes paper use. 7). Complementary documents do not need to be sent again unless requested through an account representative (Ersania and Merkusiwati, 2018).

Internet Understanding. Internet (interconnected-networking) is a series of computers that are connected in several series. In the Big Indonesian Language Dictionary (KBBI), it is explained that understanding has basic words of understanding that are intelligent and understand the processes, methods, actions (about something). In accordance with the rapid development of the internet, the internet provides many benefits for everyday life, namely: 1). users can easily obtain various information. 2). the internet provides freedom of access to search for or obtain the knowledge needed. 3). The internet provides speed in accessing various information (Lado and Budiantara, 2018). Based on these explanations, it can be concluded that understanding the internet is a true understanding of what the internet is and knowing how to use the internet.

\section{Hypothesis Development}

The effect of e-billing system implementation on taxpayer compliance. The e-Billing system is a system of paying taxes through electronic media by utilizing billing codes as transaction codes. Tax payments can be made via ATM, internet banking, or through the post office using the billing code. In the perception of ease in the TAM theory states that the e-Billing system can be accepted by taxpayers if it is easy to operate so that it will increase taxpayer compliance in the process of paying taxes. While research by (Ersania and Merkusiwati, 2018) and (Handayani, 2017) states that the application of e-Billing systems has a positive and significant influence on tax compliance. From the statement, the hypothesis in this study are:

$H_{1}$ : The application of the e-billing system is thought to have a positive effect on taxpayer compliance

The effect of the implementation of the e-filing system on taxpayer compliance. The e-Filing application is part of the tax administration system that is used to deliver Notification (SPT) online and real time to the tax office. In the perception of usability in the TAM theory states that the e-Filing system can be accepted by taxpayers if by using this online system the Notification (SPT) can be done quickly, safely, and precisely compared to manual systems that require a lot of time, so that taxpayers no need to come to the tax office again. The results of research conducted by (Agustiningsih and Isroah, 2016) and (Jayanti, 2017) show that the application of e-Filing system has a positive and significant effect on tax compliance. From the statement, the hypothesis in this study are: 


\section{$\mathrm{H}_{2}$ : The application of the e-Filing system is thought to have a positive effect on} taxpayer compliance

The effect of the implementation of e-filing system and internet understanding on taxpayer compliance. The e-Filing System is a way of delivering an Notice of Letter (SPT) online that provides convenience, speed and efficiency. In order to use the e-Filing system, taxpayers are required to have an understanding of the internet. By understanding the internet it makes it easier for taxpayers to access this system (Surendran, 2012). In the internal attribution theory states that taxpayers who understand the internet will make it easier for them when accessing the e-Filing system so that the submission of Notification (SPT) can be done well. The results of the research conducted by (Suprayogo and Hasymi, 2018) show that understanding the internet strengthens the effect of implementing the eFiling system on tax compliance. From the statement, the hypothesis in this study are:

H3: Internet understanding is thought to be able to strengthen the positive relationship of the effect of the implementation of the e-Filing system on tax compliance

Research Framework. Based on a literature review and hypothesis development above, in this study, the research framework is shown in the following figure 1:

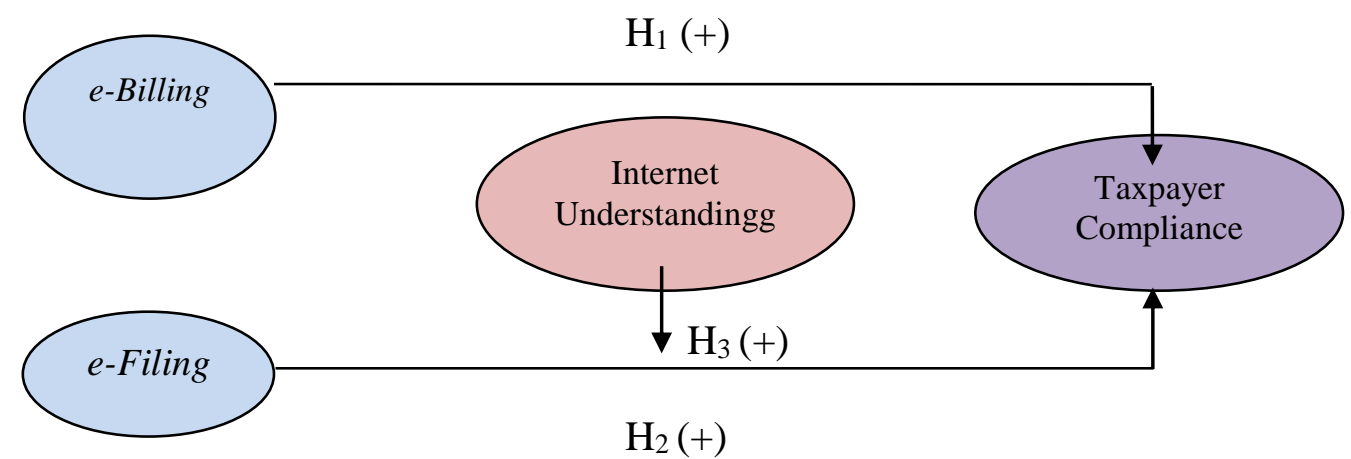

Figure 1. Research Framework

Source: (Author processed, 2019)

Based on figure 1. the framework of the above research shows that the application of eBilling and e-Filing systems is an independent variable that affects the dependent variable of taxpayer compliance. Internet understanding functions as a moderating variable that is thought to strengthen the positive relationship between the application of the e-Filing system to tax compliance.

\section{METHODOLOGY}

The population in this study is an individual taxpayer registered at Semarang Candisari Pratama Tax Office. This study uses purposive sampling in determining the sample by the criteria of individual employeetaxpayers who have two or more different 
sources of income and individual non-employeetaxpayers who have applied e-Billing and e-Filing. Number of samples used in research is 105 respondents.

Data Collection Method. In this study, the technique of the data collection applied by researchers was to use survey techniques with questionnaires to assist respondents in the study concerned (Sugiyono, 2012). Respondents were asked to give answers according to their opinions. The indicators in the variables that had been described were developed into items written statements in the questionnaire using the Likert scale with five answer choices, including: Strongly Agree (SS), Agree (S), Neutral (N), Disagree (TS), and Very Disagree (STS). Measurements of respondents' answers were done with a Likert scale 1-5.

Research Instrument. Compliance with taxpayers is when taxpayers fulfill all tax obligations and carry out their taxation rights (Lado and Budiantara, 2018). The dimensions developed in the variable taxpayer compliance are seen in aspect 1). obedience in registering, 2). compliance in the calculation and payment of tax payable, 3). compliance in payment of tax arrears, and 4). compliance to report back Notification Letter (SPT). The three dimensions described in the research instrument consist of 4 questions: 1). I registered as a taxpayer to fulfill my obligations as a good citizen, 2). I will calculate and pay taxes owed honestly and correctly, 3). I have no tax arrears so that it is easy to administer tax administration, and 4). I will report the Notification (SPT) on time and will not cheat the Notification Letter (SPT) form.

The application of the e-Billing system is an online payment tax owed system where taxpayers can pay their tax obligations online via ATM, internet banking, bank or post office so that taxpayers no longer need to come to the Tax Office to pay their taxes (Handayani, 2017). The dimensions developed in the variable implementation of the eBilling system are seen in aspect 1). understanding of taxpayers regarding the use of eBilling systems, 2). taxpayer perceptions regarding the ease of e-Billing, and 3). taxpayer perceptions regarding the usefulness of the e-Billing system. The three dimensions described in the research instrument consist of 6 questions: 1). I am a taxpayer, aware of the Directorate General of Tax regulations regarding e-Billing, 2). The Directorate General of Taxes has carried out widespread information on the application of e-Billing to taxpayers, 3). As a taxpayer, I understand the benefits, objectives and procedures for implementing the e-Billing for us, 4). e-Billing makes it easier for taxpayers to carry out tax obligations (paying tax payable), 5). e-Billing makes my time not wasted because I can pay taxes through banks, post offices and ATMs, and 6). I am satisfied with the service of the e-Billing system.

The application of the e-Filing system is a method of submitting a Notice of Return (SPT) or submission of an extension of the Annual Notification (SPT) online through the Directorate General of Tax web or application service provider (Agustiningsih and Isroah, 2016). The dimensions developed in the variable implementation of the e-Filing system are seen in aspect 1). Understanding of taxpayers regarding the use of e-Filing systems, 2). understanding of tax regulations, 3). taxpayer perceptions regarding the ease of e-Filing, and 4). perception of taxpayers regarding the usefulness of e-Filing.The four dimensions 
described in the research instrument consist of 6 questions: 1). I am a taxpayer, aware of the Directorate General of Tax regulations regarding e-Filing, 2). The Directorate General of Taxes has carried out widespread information on the application of e-Filing to taxpayers, 3). As a taxpayer, I understand the benefits, objectives and procedures for implementing e-Filing for us, 4). e-Filing makes it easier for taxpayers to carry out tax obligations (SPT reporting), 5). I can save costs and energy when using e-Filing to report SPT, and 6). I am satisfied with the service of the e-Filing system.

Understanding the Internet is the ability to be able to understand something with the help of communication networks that are connected between computers that are so vast that we can understand things easily and quickly (Lado and Budiantara, 2018). The dimensions developed in the internet understanding variable are seen in aspect 1). ease in obtaining information, 2). can add knowledge, and 3). speed in accessing. The three dimensions described in the research instrument consist of 6 questions: 1). The internet makes it easy for me to get information about the development of e-Filing, 2). The internet makes it easy for me to get guidance regarding the procedure for using e-Filing, 3). With the availability of the internet, it is easier for me to get knowledge related to laws and regulations regarding taxation, 4). With the internet, it makes it easy for me to get knowledge about tax calculation procedures, 5). The internet provides speed in accessing the submission of my tax notice, and 6). The internet provides speed of verification in the e-Filing process.

Data Analysis Method. This study will use a PLS-SEM approach. A PLS-SEM approach is adopted because it can overcome the reflective and formative models which are involved in the proposed model.

Regression Equation Formula:

$$
\mathrm{Y}=\alpha+\mathrm{B}_{1} \mathrm{X}_{1}+\mathrm{B}_{2} \mathrm{X}_{2}+\mathrm{B}_{3}\left(\mathrm{X}_{2} \mathrm{M}_{1}\right)+\varepsilon
$$

Description: $\mathrm{Y}=$ Taxpayer Compliance; $\mathrm{B}_{1}-\mathrm{B}_{3}=$ direction of regression coefficient; $\mathrm{X}_{1}=$ e-Billing system; $\mathrm{X}_{2}=\mathrm{e}$-Filing System; $\mathrm{X}_{2} \mathrm{M}_{1}=$ Interaction between the Application of eFiling Systems and Understanding of the Internet; $\varepsilon=$ error term.

\section{THE RESULT OF STATITICAL TEST}

Description of Respondents. The general description of the respondents can be seen through the respondents' demographics. Demographics of respondents in this study include age, sex, education, and occupation.

Table 3. Age of the Respondents

\begin{tabular}{ccc}
\hline Age $($ year $)$ & Frequency & Percentage \\
\hline $20-29$ & 57 & $54 \%$ \\
$30-39$ & 23 & $22 \%$ \\
$40-49$ & 22 & $21 \%$ \\
$50-59$ & 3 & $3 \%$ \\
\hline Total & 105 & $100 \%$ \\
\hline
\end{tabular}

Source: (primary data processed, 2019) 
Based on table 3. It can be seen that there were 57 respondents aged between 20-29 years (54\%), followed by 23 respondents of 30-39 years of age (22\%), then 22 respondents whose age between $40-49$ years $(21 \%)$, and those aged 50-59 years as many as 3 persons $(3 \%)$.

Table 4. Sex of the Respondents

\begin{tabular}{clcc}
\hline No & Sex & Frequency & Percentage \\
\hline 1 & Male & 63 & $60 \%$ \\
2 & Female & 42 & $40 \%$ \\
\hline Total & & 105 & $100 \%$ \\
\hline
\end{tabular}

Source: (primary data processed, 2019)

Based on table 4. It can be seen that there were 63 male respondents (60\%), and 42 female respondents $(40 \%)$.

Table 5. Education Background of the Respondents

\begin{tabular}{clcc}
\hline No & \multicolumn{1}{c}{ Education } & Frequency & Percentage \\
\hline 1 & High School & 27 & $26 \%$ \\
2 & Diploma & 16 & $15 \%$ \\
3 & Under Graduate & 54 & $51 \%$ \\
4 & Graduate & 4 & $4 \%$ \\
5 & Others & 4 & $4 \%$ \\
\hline \multicolumn{2}{c}{ Total } & 105 & $100 \%$ \\
\hline
\end{tabular}

Source: (primary data processed, 2019)

Based on table 5 , it can be seen that there were 27 respondents with a high school level (26\%), 16 Diploma level (15\%), 54 undergraduate level (51\%), 4 Master's level $(4 \%)$, and 4 respondents from other levels (4\%). In this study the respondents included in the other education categories were Vocational School.

Table 6. The Occupancy of the Respondents

\begin{tabular}{clcc}
\hline No & Occupancy & Frequency & percentage \\
\hline 1 & Trading & 22 & $21 \%$ \\
2 & Services & 46 & $44 \%$ \\
3 & Industry & 1 & $1 \%$ \\
4 & Free Workers & 7 & $7 \%$ \\
5 & Others & 29 & $27 \%$ \\
\hline \multicolumn{2}{c}{ Total }
\end{tabular}

Source: (primary data processed, 2019)

Based on table 6 , it can be seen that there were 22 respondents with the type of trade work (21\%), then 46 persons from the services $(44 \%)$, then 1 person from the industries (1\%), 7 Free Workers (7\%), and 29 people other fields $(27 \%)$. In this study, respondents included in other types of work are individual taxpayers who have 2 different sources of income. 
Description of Variables. In this study the description of variables is reflected in the following table 7 :

Table 7. Descriptive Statistics

\begin{tabular}{lccccc}
\hline & $\mathrm{N}$ & Minimum & Maximum & Mean & Std. Deviation \\
\hline EB & 105 & 1,00 & 5,00 & 4,1524 &, 64720 \\
EF & 105 & 1,00 & 5,00 & 4,0286 &, 73977 \\
IU & 105 & 2,00 & 5,00 & 4,2286 &, 60855 \\
TC & 105 & 3,00 & 5,00 & 4,2286 &, 55914 \\
Valid N (listwise) & 105 & & & & \\
\hline
\end{tabular}

Source: (primary data processed, 2019)

Table 7 above shows descriptive results obtained from 105 respondents as follows: e-Billing variable has the lowest value 1 and the highest 5 with an average value of 4.1524 while the standard deviation value is 0.64720 . The average respondent's answer is 4.1524 $>3$, this indicates that the respondent has a perception of the implementation of a high eBilling system. The standard deviation value of 0.64720 is smaller than the average value indicating the results of the responses are not too far between respondents.

The e-Filing variable has the lowest value 1 and the highest 5 with an average value of 4.0286 while the standard deviation value is 0.73977 . The average respondent's answer is $4.0286>3$, this shows the respondent has a perception of the implementation of a high e-Filing system. The standard deviation value of 0.73977 is smaller than the average value indicating the results of the responses are not too far between respondents.

The internet understanding variable has the lowest value of 2 and the highest 5 with an average value of 4.2286 while the standard deviation value is 0.60855 . The average respondent's answer is $4.2286>3$, this shows that the respondents have a high perception of internet understanding. The standard deviation value of 0.60855 is smaller than the average value indicating the results of the responses are not too far between respondents.

The taxpayer compliance variable has the lowest value of 3 and the highest 5 with an average value of 4.2286 while the standard deviation value is 0.55914 . The average respondent's answer is $4.2286>3$, this indicates the respondent has a perception of high taxpayer compliance. The standard deviation value of 0.55914 is smaller than the average value indicating the results of the responses are not too far between respondents.

Data Quality Test. Data quality test was done by using the validity and reliability test. The results of the data quality test in this study are as follows:

Table 8. Loading Factor

\begin{tabular}{lclll}
\hline & E-Billing & E-Filling & Internet Understanding & Tax Payer Compliance \\
\hline EB1 & 0,806978 & & & \\
EB2 & 0,718051 & & \\
EB3 & 0,830646 & & \\
EB4 & 0,723629 & & \\
EB5 & 0,742196 & & \\
EB6 & 0,798103 & & & \\
\hline
\end{tabular}

Jurnal Akuntansi/Volume XXIII, No. 01 January 2019: 143-159 


\begin{tabular}{llll}
\hline EF1 & 0,880844 & & \\
EF2 & 0,796317 & & \\
EF3 & 0,894685 & & \\
EF4 & 0,788045 & & \\
EF5 & 0,782203 & & \\
EF6 & 0,798887 & 0,463188 & \\
IU1 & & 0,707633 & \\
IU2 & & 0,713434 & \\
IU3 & & 0,612111 & \\
IU4 & 0,737860 & 0,817561 \\
IU5 & & 0,627959 & 0,885429 \\
IU6 & 0,554323 & 0,810643 \\
IU7 & & 0,622809 & \\
IU8 & 0,690891 & \\
IU9 & & 0,635602 & \\
IU10 & & & \\
TPC1 & & & \\
TPC2 & & & \\
TPC3 & & & \\
TPC4 & & & \\
\hline
\end{tabular}

Source: (primary data processed, 2019)

Table 8. shows that the construct correlation of E-Billing, E-Filling, Internet Understanding, and Tax Payer Compliance with each indicators are higher than 0,5. It indicates that the estimated constructs fully fulfill the discriminant validity criteria.

Table 9. Average Variance Extracted (AVE)

\begin{tabular}{lcc}
\hline & AVE & $\sqrt{\text { AVE }}$ \\
\hline E-Billing & 0,594707 & 0,77117 \\
E-Filling & 0,680257 & 0,82478 \\
E-Filling * Internet Understanding & 0,633343 & 0,79583 \\
Tax Payer Compliance & 0,712403 & 0,84404 \\
\hline
\end{tabular}

Source: (primary data processed, 2019)

Table 9. shows that the $\sqrt{A V E}$ values are above 0,5 for all constructs. It can be concluded that all indicators in this study are valid.

Table 10. Composite Reliability

\begin{tabular}{lcc}
\hline & Composite Reliability & Cronbachs Alpha \\
\hline E-Billing & 0,897707 & 0,865936 \\
E-Filling & 0,927143 & 0,907799 \\
Internet Understanding & 0,873177 & 0,839434 \\
Tax Payer Compliance & 0,908216 & 0,865236 \\
\hline
\end{tabular}

Source: (primary data processed, 2019) 
Table 10. shows that the composite reliability and cronbachs alpha values for all constructs are above 0,7 . This shows that all of the estimated constructs are reliable that can be used to the further research process.

R Square Test. R Square test is done to find out to the extend independent variable influence dependent variable. The results of the R Square test in this study are as follows:

Table 11. R Square Test

\begin{tabular}{lc}
\hline & R Square \\
\hline E-Billing & \\
E-Filling & \\
E-Filling * Internet Understanding & \\
Tax Payer Compliance & 0,340758 \\
\hline \multicolumn{2}{c}{ Source: (primary data processed, 2019) }
\end{tabular}

Table 11. shows the R-square value of Tax Payer Compliance is 0,340758 which means that E-Billing, E-Filling, and E-Filling * Internet Understanding are able to explain the variance of Tax Payer Compliance by $34.08 \%$ and $65.02 \%$ is influenced by other factors that are not investigated in this study.

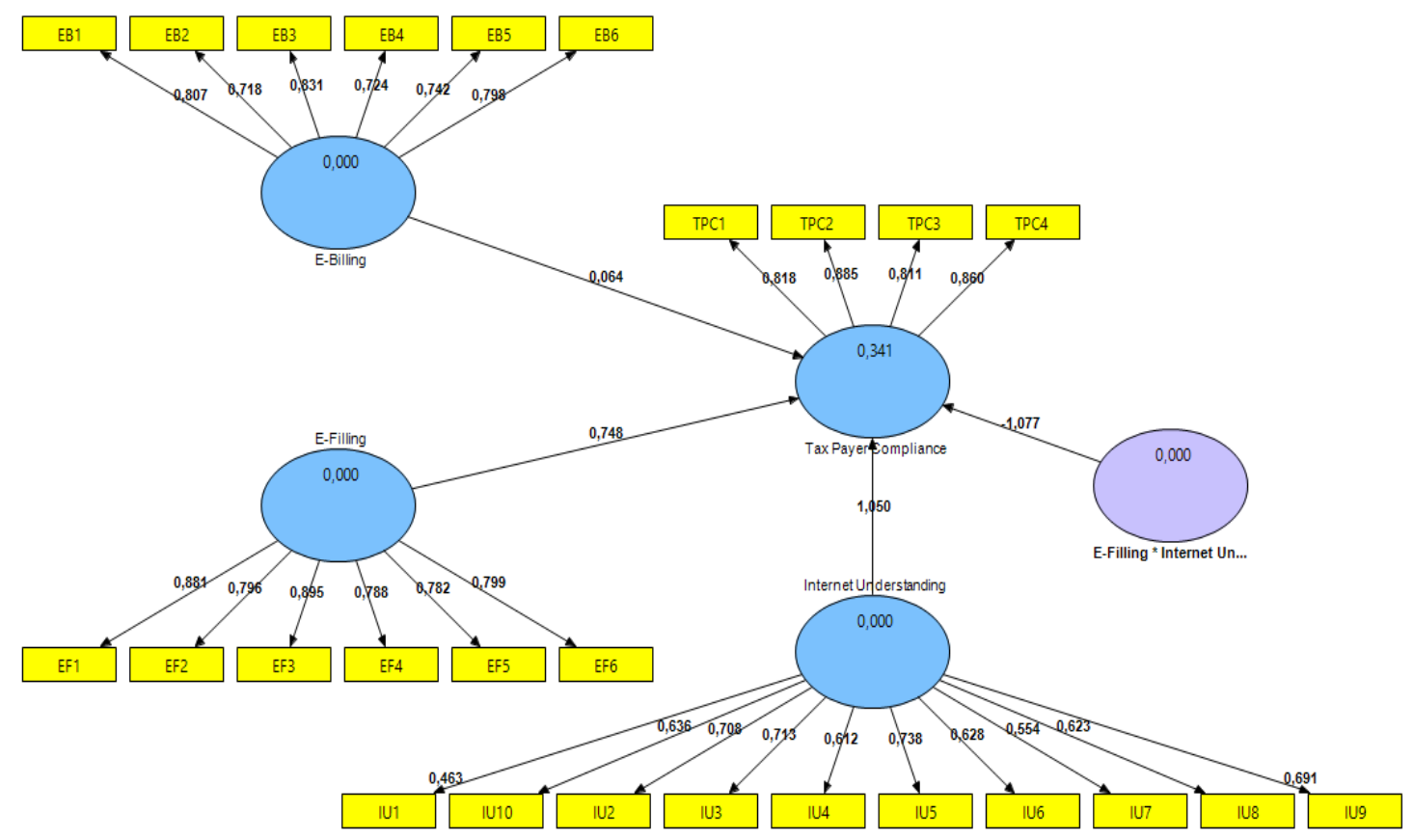

Figure 2. Findings of Structural Model

Path Coefficients Test. The path coefficients test is used to determine whether the variables in the model have simultaneous influence. The results of the path coefficients test in this study are as follows: 
Table 12. Path Coefficients

\begin{tabular}{|c|c|c|c|c|c|c|}
\hline & $\begin{array}{l}\text { Original } \\
\text { Sample }\end{array}$ & $\begin{array}{c}\text { Sample } \\
\text { Mean }\end{array}$ & $\begin{array}{c}\text { Standar } \\
\text { d } \\
\text { Deviatio } \\
\text { n } \\
\end{array}$ & $\begin{array}{l}\text { Standar } \\
\text { d Error }\end{array}$ & $\begin{array}{c}\mathbf{T} \\
\text { Statistics }\end{array}$ & Result \\
\hline $\begin{array}{l}\text { E-Billing } \rightarrow \\
\text { Compliance }\end{array}$ & 0,063831 & 0,113749 & 0,129959 & 0,129959 & 0,491160 & Rejected \\
\hline $\begin{array}{l}\text { E-Filling } \rightarrow \text { Tax } \\
\text { Compliance }\end{array}$ & 0,748413 & 0,886319 & 0,402003 & 0,402003 & 1,861709 & Accepted \\
\hline $\begin{array}{l}\text { E-Filling } * \\
\text { Understanding } \\
\text { Compliance }\end{array}$ & $\stackrel{-}{1,077105}$ & $-1,333921$ & 0,644862 & 0,644862 & 1,670286 & Accepted \\
\hline
\end{tabular}

Source: (primary data processed, 2019)

Table 12. shows that 2) the relationship between E-Billing and Tax Payer Compliance is not significant because the statistical value is smaller than table $(0,491160$ $<1,66)$ at the significance level of $5 \%$. Therefore, the first hypothesis is rejected; 2) the relationship between E-Filling and Tax Payer Compliance is significant positive effect because the statistical value is greater than t table $(1,861709>1,66)$ at the significance level of 5\%. Thus, the second hypothesis is accepted; and 3) the relationship between EFilling * Internet Understanding and Tax Payer Compliance is significant positive effect because the statistical value is greater than t table $(1,670286>1,66)$ at the significance level of 5\%. Therefore, the third hypothesis is accepted.

\section{DISCUSSION}

The effect of implementing e-Billing system on taxpayer compliance. The results in this study shows that the variables of the implementation of e-Billing systems have no significant effects on taxpayer compliance. The use of the e-Billing system has not had a significant impact because it is not yet well understood by taxpayers.In the perception of ease in the theory of TAM the use of the system can be accepted by the user if the system is easy to operate. The results of this study do not support the theory because taxpayers have not been able to use the billing system to the fullest. The results of this study are not in line with the research of (Ersania and Merkusiwati, 2018) and (Handayani, 2017) which show that the application of e-Billing systems has a positive and significant influence on taxpayer compliance.

The effect of implementing e-Filing system on tax compliance. The results in this study indicate the application of e-Filing system has a positive and significant effect on tax compliance. With the implementation of e-Filing the efficiency of delivering Notification (SPT) continues to increase. The better the implementation of e-Filing system, the taxpayer compliance will increase.In accordance with the perception of usability in the TAM theory, the e-Filing System provides convenience, speed and saves costs so that the application of the e-Filing system is more effective than the manual system. The results of this study are in line with the research conducted by (Agustiningsih and Isroah, 2016) and 
(Jayanti, 2017) which shows the results that the application of e-Filing system has a positive and significant effect on tax compliance.

The effect of internet understanding and application of e-Filing system to taxpayer compliance. There is an influence of understanding the internet and the application of the e-Filing system to tax compliance. This shows that understanding the internet as a moderating variable has succeeded in strengthening the positive relationship between the application of the e-Filing system and tax compliance. The better internet understanding a person has is able to strengthen the use of the e-Filing system so that taxpayer compliance in delivering Notification (SPT) can increase.

The results of this study support the internal attribution theory which explains that individual behavior is influenced by the factors that exist from within the individual. Taxpayers who have an understanding of the internet will certainly make it easier for them to access e-Filing because this system is applied online. On the other hand, taxpayers who do not understand the internet tend to have difficulties when using e-Filing. The results of this study are in line with the research from (Suprayogo and Hasymi, 2018) which shows the results that understanding the internet strengthens the positive relationship of the effect of implementing the e-Filing system on tax compliance.

\section{CONCLUSION}

Based on the explanationabove, conclusions are obtained as follows: The application of the e-Billing system does not affect taxpayer compliance. This shows that the effectiveness of the e-Billing system will be limited if the taxpayer's ability to run the eBilling system is also limited. So that the ease of use of e-Billing system services is one of the determinants of this system that can be accepted by taxpayers.

While the application of e-Filing system has a significant positive effect on tax compliance. This shows that the implementation of a good e-Filing system will have an impact on the increasing increase in taxpayer compliance and vice versa. The lower the implementation of the e-Filing system, the taxpayer compliance will decrease.

Understanding the internet as a moderating variable shows that understanding the internet has managed to moderate the result by strengthening the positive relationship of the application of e-Filiing system to taxpayer compliance. This shows that understanding the internet is one of the determinants of taxpayers who can operate the e-Filing system well. The better understanding of the internet will make it easier for taxpayers to access eFiling so that it will have an effect on increasing taxpayer compliance.

Limitations and Suggestions. This study cannot yet be generalized because (1) The population used is only at Semarang Candisari Pratama Tax Service Office and the number of samples in this study is limited. Future research is expected to use a wider population and sample than the city of Semarang. (2) the selection of a limited sample with the criteria of an individual taxpayer of employees who have two or more different sources of income and individual taxpayers who have never used e-Billing and e-Filing. (3) In addition to the limitations on the side of the research sample other arguments are shown in terms of the independent variables used. Where the independent variables used 
are limited to the application of e-Billing, e-Filing, and internet understanding systems. For further research, it is expected to add other independent variables such as understanding taxation and taxation socialization.

\section{REFERENCES}

Agustiningsih, W., and Isroah, I. (2016). Pengaruh Penerapan E-Filing, Tingkat Pemahaman Perpajakan dan Kesadaran Wajib Pajak Terhadap Kepatuhan Wajib Pajak di KPP Pratama Yogyakarta. Nominal, Barometer Riset Akuntansi Dan Manajemen, 5(2). https://doi.org/10.21831/nominal.v5i2.11729.

Alabede, Z., and Idris. (2012). Tax Service Quality and Compliance Behaviour in Nigeria: Do Taxpayer's Financial Condition and Risk Preference Play Any Moderating Role. Journal of Economics, Finance and Administrative Sciences, 78.

Asosiasi Penyelenggara Jasa Internet Indonesia (APJII). (2016). Penetrasi dan Perilaku Pengguna Internet Indonesia. Diambil 4 November 2018, dari https://apjii.or.id/downfile/file/surveipenetrasiinternet2016.pdf.

Direktorat Jenderal Pajak. (2018). Kepatuhan Meningkat, Penyampaian SPT Tumbuh Double Digit. Diambil 6 November 2018, dari www.pajak.go.id.

Ersania, G. A. R., and Merkusiwati, N. K. L. A. (2018). Pengaruh Penerapan e-System Perpajakan Terhadap Tingkat Kepatuhan Wajib Pajak Orang Pribadi. E-Jurnal Akuntansi Universitas Udayana, 22(3), 27.

Handayani, K. R., and Tambun, S. (2016). Pengaruh Penerapan Sistem E-Filing dan Pengetahuan Perpajakan Terhadap Kepatuhan Wajib Pajak Dengan Sosialisasi Sebagai Variabel Moderating (Survei pada Perkantoran Sunrise Garden di Wilayah Kedoya, Jakarta Barat). Media Akuntansi Perpajakan, 1(2), 59-73.

Handayani, W. (2017). Pengaruh Penerapan Billing System Terhadap Kepatuhan Wajib Pajak Dengan Moderasi Pemahaman Perpajakan (Studi Pada KPP Pratama Surabaya Karangpilang). Jurnal Ekonomi Akuntansi, 3(4), 14.

Jayanti, E. D. (2017). Pengaruh Penerapan Sistem e-Filing, Pemahaman Perpajakan dan Kesadaran Wajib Pajak Terhadap Kepatuhan Wajib Pajak. STIE Perbanas Surabaya, 20.

KEP-88 / PJ / 2004 Tentang Penyampaian Surat Pemberitahuan Secara Elektronik. (2004).

Lado, Y. O., and Budiantara, M. (2018). Pengaruh Penerapan Sistem e-Filing Terhadap Kepatuhan Wajib Pajak Orang Pribadi Pegawai Negeri Sipil dengan Pemahaman Internet Sebagai Variabel Pemoderasi (Studi Kasus pada Dinas Perindustrian dan Perdagangan DIY). JRAMB, Prodi Akuntansi, Fakultas Ekonomi, UMB Yogyakarta, 4(1), 26.

Mardiasmo. (2016). Perpajakan (2016 ed.). Yogyakarta: Andi.

Oktaviani, R. M., dan Chusaeni, B. F. (2018). Penguasaan Teknologi Informasi sebagai Pemoderasi Kecenderungan Wajib Pajak Menggunakan E-Filing. Jurnal Ekonomi Modernisasi, 14(1), 16-27. https://doi.org/10.21067/jem.v14i1.2376.

Oktaviani, R. M., Hardiningsih, P., dan Srimindarti, C. (2017). Kepatuhan Wajib Pajak Memediasi Determinan Penerimaan Pajak Penghasilan. Jurnal Akuntansi, 21(2), 318-335. https://doi.org/10.24912/ja.v21i2.201. 
PER-26/PJ/2014 Tentang Sistem Pembayaran Pajak Secara Elektronik. (2014).

PMK 192/PMK.03/2007Tentang Wajib Pajak dengan Kriteria Tertentu dalam Rangka Pengembalian Pendahuluan Kelebihan Pembayaran Pajak. (2007).

Rahmah, T. S., Fauziati, P., dan Muslim, R. Y. (2018). Pengaruh Penerapan E-System Perpajakan dan Sanksi Pajak Terhadap Kepatuhan Wajib Pajak (Studi Kasus Pada KPP Pratama Padang Dua). Jurnal Fakultas Ekonomi, 13(1). Diambil dari http://ejurnal.bunghatta.ac.id/index.php?journal=JFEK\&page=article\&op=view\&pat $\mathrm{h} \% 5 \mathrm{~B} \% 5 \mathrm{D}=12615$.

Rahman, A. (2010). Administrasi Perpajakan. Bandung: Nuansa.

SE-47/PJ/2008 Tentang Pencabutan Surat Edaran Direktur Jenderal Pajak Dan Surat Penegasan Tentang Penggunaan Metode Q.Q. Pada Faktur Pajak Standar. (2008).

Shroff, R. H., and Deneen, C. C. (2012). Analysis of the technology acceptance model in examining students' behavioural intention to use an e-portfolio system. Australasian Journal of Educational Technology, 27(4), 600-618. https://doi.org/10.14742/ ajet.940.

Sugiyono. (2012). Metode Penelitian Bisnis. Bandung: Alfabeta.

Suprayogo, S., dan Hasymi, M. (2018). Pengaruh Penerapan Sistem E-Filing Terhadap Kepatuhan Wajib Pajak Orang Pribadi dengan Pemahaman Internet Sebagai Variabel Moderasi pada Kantor Pelayanan Pajak Pratama Jakarta Jatinegara. Jurnal Profita, 11(2), 151. https://doi.org/10.22441/profita.2018.v11.02.001.

Surendran, P. (2012). Technology Acceptance Model: A Survey of Literature. International Journal of Business and Social Research (IJBSR), 2(4), 175-178.

Tresno, I. P., dan Rizky, S. A. (2012). Pengaruh Persepsi Penerapan Sistem E-Filling terhadap Tingkat Kepatuhan Wajib Pajak Badan Dengan Perilaku Wajib Pajak Sebagai Variabel Intervening dan Biaya Kepatuhan Sebagai Variabel Moderasi (Studi Kasus Pada Kantor Pelayanan Pajak Pratama Pulogadung Jakarta Timur). Dipresentasikan pada Simposium Nasional Perpajakan 4, Jakarta. 